\title{
Biotechnology Governance 2.0: A Proposal for Minimum Standards in Biotechnology Corporate Governance
}

\author{
Carter, A.R. ${ }^{1}$, Meinert, E. ${ }^{1}$ \& Brindley, D.A. ${ }^{1 *}$ \\ ${ }^{1}$ University of Oxford, Healthcare Translation Research Group, Department of Paediatrics, Oxford, United \\ Kingdom
}

Authors for Correspondence: david.brindley@paediatrics.ox.ac.uk and alison.carter@paediatrics.ox.ac.uk

\author{
Abstract Word Count: 151
}

Overall: Word Count: 4229

\begin{abstract}
Based on experience and the existing limited research literature in biotechnology corporate governance, the authors propose potential attributes of minimum corporate governance standards for biotechnology companies, as a basis for further quantitative and qualitative research. The authors assert that the recent proliferation of biotechnology start-up organisations is substantively changing inter- and intra-organizational cultures throughout the healthcare sector via a 'cascade of governance'. Therefore, governance decisions and actions - both positive and negative - that are instituted in start-up biotech companies may set new norms for other start-up biotech companies, the larger (bio)pharmaceutical companies by which they are acquired and the range of healthcare sub-sector actors that interact with biotechnology companies.
\end{abstract}

The authors stress the importance of appropriate, proportionate and consistent biotech corporate governance throughout company lifecycles, not simply to support value inflection or as a response to a crisis. Fail to govern, fail to succeed - for investors and, most importantly, for patients.

\section{The Criticality of Corporate Governance to all Biotechnology Stakeholders}

\section{The Context and Potential Consequences of Failing to Govern Biotechnology Companies Effectively}

The proliferation of biotechnology start-ups has been precipitated in part by the decline of conventional pharmaceutical company internal research and development (R\&D) and in part by shifts in incentives for academic inventors to 'spin-out' their technologies (Backhaus, 2015). This system-level shift within the sector has brought with it some significant challenges, perhaps most significant of all being corporate governance (Carter et al, 2018). Unfortunately, corporate governance is rarely discussed proactively in biotechnology startups; instead, it is often viewed as the onslaught of a rather unsavoury series of structures and processes instituted externally when something goes wrong.

Herein, the authors propose - proactively and deliberately - that corporate governance is the most significant challenge to and fundamentally the keystone to developing a durable start-up biotechnology industry. It eclipses the 'biotech holy trinity' of good science, good people and the availability of financial capital (Stromsten, 2012). This hypothesis is built upon the reductionist view that in the absence of good biotech corporate governance, only two outcomes for the start-up biotech sector and individual companies within it exist, both existential.

Either the short-term absence of effective corporate governance leads to poor decision making in the allocation of resources relating to science, people or financial capital, yielding laggards that are outcompeted gradually by more effectively governed entities (Wen-Chung, 2012). Alternatively, those entities that obtain critical mass and substantial growth without proactively investing in a robust foundation of corporate governance will fail precipitously, often during a significant value inflection or transaction, upon the discovery of a major organizational or technological deficiency that could have been avoided or mitigated by good governance. 
The equation is simple - fail to govern, fail to succeed.

\section{Definition of Corporate Governance}

The central aim of corporate governance is to effectively manage the risks of an organisation, in particular, the agency relationships between stakeholders, to optimise the outcome of resource deployment by the organisation measured against pre-determined objectives (Lo Nigro, 2012). For example, in biotech, patients and patient groups may be considered a stakeholder in the context of corporate governance, in addition to conventional stakeholders, such as shareholders and regulators (Daines, 2010). This is the definition and spirit of corporate governance that will be adopted by the authors herein. However, for completeness, exemplar scholarly, governmental and industry definitions and explanations are provided in TABLE 1.0.

\begin{tabular}{|c|c|}
\hline Definition of Corporate Governance & Reference \\
\hline $\begin{array}{l}\text { "Corporate Governance is about promoting } \\
\text { corporate fairness, transparency and accountability" }\end{array}$ & $\begin{array}{l}\text { James Wolfensohn, former President of the World } \\
\text { Bank Group, as quoted by an article in Financial } \\
\text { Times, } 21 \text { June } 1999\end{array}$ \\
\hline $\begin{array}{l}\text { "Corporate Governance is concerned with holding } \\
\text { the balance between economic and social goals and } \\
\text { between individual and communal goals. The } \\
\text { corporate governance framework is there to } \\
\text { encourage the efficient use of resources and equally } \\
\text { to require accountability for the stewardship of those } \\
\text { resources. The aim is to align as nearly as possible the } \\
\text { interests of individuals, corporations and society" }\end{array}$ & $\begin{array}{l}\text { Sir Adrian Cadbury in 'Global Corporate Governance } \\
\text { Forum', World Bank, } 2000\end{array}$ \\
\hline $\begin{array}{l}\text { "the purpose of corporate governance is to help build } \\
\text { an environment of trust, transparency and } \\
\text { accountability necessary for fostering long-term } \\
\text { investment, financial stability and business integrity, } \\
\text { thereby supporting stronger growth and more } \\
\text { inclusive societies" }\end{array}$ & G20/OECD Principles of Corporate Governance, 2015 \\
\hline $\begin{array}{l}\text { "the processes and structure by which the business } \\
\text { and affairs of the company are directed and } \\
\text { managed, in order to enhance long term shareholder } \\
\text { value through enhancing corporate performance and } \\
\text { accountability, whilst taking into account the } \\
\text { interests of other stakeholders. Good corporate } \\
\text { governance therefore embodies both enterprise } \\
\text { (performance) and accountability (conformance)" }\end{array}$ & $\begin{array}{l}\text { 'The Report of the Committee and The Code of } \\
\text { Corporate Governance' produced by The Committee } \\
\text { on Corporate Governance or CGC, Monetary } \\
\text { Authority of Singapore, } 21 \text { March } 2001\end{array}$ \\
\hline $\begin{array}{l}\text { "allocation of ownership, capital structure, } \\
\text { managerial incentive schemes, takeovers, board of } \\
\text { directors, pressure from institutional investors, } \\
\text { product market competition, labour market } \\
\text { competition, organisational structure, etc., can all be } \\
\text { thought of as institutions that affect the process } \\
\text { through which quasi-rents are distributed" }\end{array}$ & $\begin{array}{l}\text { Luigi Zingales, 'Corporate Governance'. In Peter } \\
\text { Newman (Ed.), The New Palgrave Dictionary of } \\
\text { Economics and the Law (pp. 497-502), London: } \\
\text { Macmillan, } 1998\end{array}$ \\
\hline $\begin{array}{l}\text { "governance determines how the firm's top decision } \\
\text { makers (executives) actually administer such } \\
\text { contracts" }\end{array}$ & $\begin{array}{l}\text { Peter Swan \& Gerald Garvey, 'The Economics of } \\
\text { Corporate Governance: Beyond the Marshallian } \\
\text { Firm', Journal of Corporate Finance, } 1994\end{array}$ \\
\hline
\end{tabular}


"the ways in which suppliers of finance to corporations assure themselves of getting a return on their investment"
Andrei Shleifer \& Robert W. Vishny, 'A Survey of Corporate Governance', The Journal of Finance, 1997

Most notable from TABLE 1.0 is how existing definitions of corporate governance are poorly tailored to biotech. In particular, the frequently narrow focus of stakeholder requirements as financially orientated, omitting the absolute requirement for biotech companies to deliver social value, as a minimum, through patient benefits (Hogarth, 2010).

The existing definitions of corporate governance set forth also fail to refer to unique moral hazards in biotechnology, not least, that all research is conducted in an ethical manner (Caulfield, 2006). Nor do existing definitions convey the need for continuous monitoring and improvement of corporate governance, a principle that is pervasive throughout GxP biotech operations - and implicit within empirical methods upon which biotech is built (Nielsen, 2010).

Therefore, it is worth considering what exactly these authors mean by biotech. Namely, what is the context of the evaluation and recommendations herein, and to which stakeholders they refer.

\section{Scope of the Biotechnology Sector Pertaining to Corporate Governance and Relationship to Life Sciences, Pharmaceutical, Healthcare and 'Other' Sectors}

Healthcare, pharma, biotech and 'other healthcare terms' have assumed an erroneous synonymous connotation in specialist and non-specialist vernacular. This is in part due to longstanding mechanisms of exchange between these respective sectors, including intellectual property (IP); human capital; shared third parties, including suppliers and customers; and shared regulations and standards, most notably GxP. For example, tools and technology companies may provide a given reagent or consumable to pharma, biotech, medical device and hospital clients.

There are two core ways to define healthcare related industries, either by their offering (technologies and services) [FIGURE 1.0] adapted from Brindley et al 2015, or by their role(s) within the value chain enabling the development, production, implementation and distribution supporting the delivery of an offering (technologies and services). Perhaps more elegantly, there is a distinction between organisations that offer a final product or service, and those that assist other organisations in offering a final product or service [TABLE 2.0].

Figure 1: The 21st-century pharmacopeia, including the convergence of "regenerative medicine" therapeutic approaches

\begin{tabular}{|c|c|c|c|c|}
\hline \multicolumn{4}{|c|}{ THERAPEUTICS } & DEVICES \\
\hline \multirow{4}{*}{$\begin{array}{c}\text { Small } \\
\text { Molecules } \\
\text { (e.g, imatinib) }\end{array}$} & \multirow{2}{*}{\multicolumn{3}{|c|}{$\begin{array}{c}\text { BIOLOGICS } \\
\text { Monoclonal } \\
\text { Antibody } \\
\text { (e.g., trastuzumab) }\end{array}$}} & Medical \\
\hline & & & & $\begin{array}{c}\text { Devices } \\
\text { (e.g., stents) }\end{array}$ \\
\hline & $\begin{array}{l}\text { Cell Therapy } \\
\text { (e.g., MSCs) }\end{array}$ & $\begin{array}{c}\text { Immuno } \\
\text { Therapy } \\
\text { (e.g., chimeric antigen } \\
\text { receptor-modified } \\
\text { T cells) }\end{array}$ & $\begin{array}{c}\text { Gene } \\
\text { Therapy } \\
\text { (e.g., alipogene } \\
\text { tiparvovec) }\end{array}$ & \multirow[t]{2}{*}{$\begin{array}{c}\text { Tissue } \\
\text { Engineering } \\
\text { (e.g, skin grafts) }\end{array}$} \\
\hline & \multicolumn{3}{|c|}{ REGENERATIVE MEDICINE } & \\
\hline \multicolumn{4}{|c|}{ COMBINATIONAL THERAPEUTICS } & \\
\hline
\end{tabular}


Table 2.0: Distinction of Healthcare Sub-sectors

\begin{tabular}{|c|c|}
\hline Sub-Sector Type & Description \\
\hline Pharmaceutical & $\begin{array}{l}\text { Conventional pharmaceutical } \\
\text { sector originally based upon small } \\
\text { molecule therapeutics. Larger } \\
\text { pharmaceutical companies may } \\
\text { include multiple divisions } \\
\text { including all sub-sectors. May } \\
\text { includes vaccines. }\end{array}$ \\
\hline Biotechnology & $\begin{array}{l}\text { Focused on biological therapies, } \\
\text { including monoclonal antibodies } \\
\text { (mAbs). May include vaccines and } \\
\text { mature regenerative medicine } \\
\text { companies. }\end{array}$ \\
\hline Diagnostics & $\begin{array}{l}\text { Full spectrum of diagnostic } \\
\text { technologies, potentially including } \\
\text { companion diagnostics. }\end{array}$ \\
\hline Tools and Technologies & $\begin{array}{l}\text { Providers of reagents, } \\
\text { technologies and equipment to all } \\
\text { sub-sectors. }\end{array}$ \\
\hline Bioprocess & $\begin{array}{l}\text { Providers of manufacturing } \\
\text { equipment to sub-sector clients, } \\
\text { particularly cGMP products and } \\
\text { services. }\end{array}$ \\
\hline Digital Health & $\begin{array}{l}\text { Data intensive technologies that } \\
\text { may be used for target } \\
\text { identification, treatment and } \\
\text { pharmacoepidemiology. }\end{array}$ \\
\hline Distribution & $\begin{array}{l}\text { Validated, qualified and controlled } \\
\text { distribution of products often to } \\
\text { GDP. }\end{array}$ \\
\hline Blood Products & $\begin{array}{l}\text { Blood product collection, } \\
\text { processing and storage. }\end{array}$ \\
\hline Healthcare Provision & $\begin{array}{l}\text { Primary, secondary and tertiary } \\
\text { caregiving - including hospitals, } \\
\text { specialist treatment centres. }\end{array}$ \\
\hline CROs & $\begin{array}{l}\text { Providers of research function } \\
\text { support. Major classes of CRO } \\
\text { provide clinical trial support and } \\
\text { co-ordination, and third party } \\
\text { independent testing and } \\
\text { validation of products and } \\
\text { services. }\end{array}$ \\
\hline CMOs & $\begin{array}{l}\text { Providers of manufacturing } \\
\text { services, often to cGMP. }\end{array}$ \\
\hline
\end{tabular}

The scope and context of corporate governance recommendations provided by the authors herein is focused primarily on biotechnology companies, including start-up or independent vaccine companies. Therefore, it will not include some areas such as drug pricing and distribution that have been subject to previous research (Fidler, A. and Msisha,W., 2008). However, the recommendations provided may be applicable - in whole or in part - to other sub-sectors should the particular entity in question share a significant proportion of classical biotechnology company characteristics. 


\section{Characteristics of Biotechnology Companies}

Implicit in the necessity for biotechnology minimum corporate governance standards is that biotechnology companies have a number of unique characteristics, and therein specific governance requirements, compared to non-biotechnology entities. For example, biotechnology companies are inherently R\&D intensive, highly regulated, capital intensive, high (investment and execution) risk(s), and technologically complex (Billitteri, 2013).

These specific governance requirements can be further classified into: unavoidable or intrinsic and constant corporate governance challenges in biotechnology - characteristics that cannot be changed by management or governance; unavoidable or intrinsic and variable corporate governance challenges in biotechnology-attributes that it may be possible to change and/or mitigated by management or governance [Table 3.0]. In either category of requirement, it is vital that these inherent characteristics - and associated risks and opportunities - are monitored via a continuous and transparent method such as a risk register that is communicated to stakeholders who can affect appropriate action(s). 
Table 3.0: Comparison of Constant and Variable Unavoidable or Intrinsic Biotechnology Corporate Governance Challenges

\begin{tabular}{|c|c|c|c|}
\hline \multicolumn{2}{|c|}{$\begin{array}{l}\text { Constant and Unavoidable or Intrinsic Biotechnology Corporate Governance } \\
\text { Challenges }\end{array}$} & \multicolumn{2}{|c|}{$\begin{array}{l}\text { Variable and Unavoidable or Intrinsic Biotechnology Corporate Governance } \\
\text { Challenges }\end{array}$} \\
\hline Challenge & Description & Challenge & Description \\
\hline $\begin{array}{l}\text { International differences }- \text { limited } \\
\text { harmonization }\end{array}$ & $\begin{array}{l}\text { Most biotechnology companies are } \\
\text { international in operations, and } \\
\text { certainly in technology deployment. } \\
\text { Often significant differences exist in } \\
\text { operating cultures, corporate } \\
\text { expectations and regulations between } \\
\text { territories. }\end{array}$ & Dominant (scientific) founder & $\begin{array}{l}\text { Scientific founders who provided the } \\
\text { intellectual substrate to the formation of } \\
\text { a biotechnology company may } \\
\text { intentionally or unintentionally exert } \\
\text { significant control during company } \\
\text { development. This may or may not be in } \\
\text { the best interests of the company at all } \\
\text { stages of the company lifestyle. }\end{array}$ \\
\hline Highly regulated & $\begin{array}{l}\text { All aspects of biotechnology are highly } \\
\text { regulated, particularly, manufacturing } \\
(\mathrm{CMC}) \text {, (patient) data, clinical trials. }\end{array}$ & Dominant (early stage) investor & $\begin{array}{l}\text { Early stage investors who provided the } \\
\text { initial financial capital to support the } \\
\text { formation of a biotechnology company } \\
\text { may intentionally or unintentionally } \\
\text { exert significant control during company } \\
\text { development. This may or may not be in } \\
\text { the best interests of the company at all } \\
\text { stages of the company lifestyle. }\end{array}$ \\
\hline Technically complex & $\begin{array}{l}\text { The core scientific platforms being } \\
\text { developed towards commercialisation, } \\
\text { and the technologies used to develop } \\
\text { such platforms is technically complex. }\end{array}$ & Unexpected growth & $\begin{array}{l}\text { Biotechnology companies often } \\
\text { experience unexpected exponential } \\
\text { growth in response to internal or } \\
\text { external events, the timing of which is } \\
\text { difficult to predict. For example, proof of } \\
\text { concept data (internal) and/or co- } \\
\text { development opportunities with larger } \\
\text { (bio)pharmaceutical companies or } \\
\text { disease foundations (external). }\end{array}$ \\
\hline Operationally complex & $\begin{array}{l}\text { All biotechnology companies are } \\
\text { inherently operationally complex, even } \\
\text { in early years of operation, due to }\end{array}$ & Non-specialist investors & $\begin{array}{l}\text { Growth in biotechnology as an asset } \\
\text { class for private investors has led to an } \\
\text { increase in non-specialist investors in }\end{array}$ \\
\hline
\end{tabular}




\begin{tabular}{|c|c|c|c|}
\hline & $\begin{array}{l}\text { significant segregation of functions } \\
\text { arising from regulatory requirements, } \\
\text { domain specific expertise and/or } \\
\text { stemming from technical complexities of } \\
\text { technologies. }\end{array}$ & & $\begin{array}{l}\text { the sector mainly from family offices. } \\
\text { The beneficial owners of these family } \\
\text { offices and/or the individuals to whom } \\
\text { responsibility is delegated for } \\
\text { biotechnology investments may not be } \\
\text { experienced or appropriately skilled in } \\
\text { biotechnology and/or governance. }\end{array}$ \\
\hline Multi-stakeholder & $\begin{array}{l}\text { Complex and interdependent multi- } \\
\text { stakeholder requirements arising from } \\
\text { internal and external stakeholders. }\end{array}$ & $\begin{array}{l}\text { Specialist investors, unfamiliar with } \\
\text { specific novel technology }\end{array}$ & $\begin{array}{l}\text { The recent growth in novel technological } \\
\text { platforms such as siRNA and digital } \\
\text { health technologies has contributed to a } \\
\text { unique situation where experienced } \\
\text { biotechnology investors by definition } \\
\text { have limited experience in these } \\
\text { 'vanguard' technologies. }\end{array}$ \\
\hline Collaborative & $\begin{array}{l}\text { Almost all functions of biotechnology } \\
\text { organisations are collaborative. For } \\
\text { example, arising from collaborative R\&D } \\
\text { efforts and vertically integrated } \\
\text { operational models with third party } \\
\text { specialist vendors. }\end{array}$ & Inexperienced Board Members & $\begin{array}{l}\text { Early stage biotechnology companies } \\
\text { often have inexperienced Board } \\
\text { Members; for example, appointed by } \\
\text { non-specialist investors or academic } \\
\text { founders. This is often characterised by } \\
\text { a poor segregation of responsibilities } \\
\text { between management and governance, } \\
\text { with Board Members seeking to manage } \\
\text { aspects of the organisation. High risk of } \\
\text { subjectivity and inappropriate agency } \\
\text { relationships in decision making. }\end{array}$ \\
\hline IP Intensive & $\begin{array}{l}\text { IP generation, maintenance, protection } \\
\text { and monitoring are critical at all stages } \\
\text { of biotechnology company } \\
\text { development. }\end{array}$ & $\begin{array}{l}\text { 'Control and ownership vs mechanisms } \\
\text { and controls' }\end{array}$ & $\begin{array}{l}\text { Early stage biotechnology companies, } \\
\text { particularly those with investors and/or } \\
\text { Board Members who are from a non- } \\
\text { biotechnology background often } \\
\text { conflate 'control and ownership vs } \\
\text { mechanisms and controls'. Therefore, } \\
\text { inappropriate emphasis is placed on } \\
\text { specific management decisions as } \\
\text { opposed to an investment into and } \\
\text { implementation of durable processes to } \\
\text { deliver decision making reproducibly. }\end{array}$ \\
\hline
\end{tabular}




\begin{tabular}{|c|c|c|c|}
\hline Specialized facilities & $\begin{array}{l}\text { Specialized facilities and equipment are } \\
\text { required for a number of functions, } \\
\text { including R\&D and manufacturing to GLP } \\
\text { and GMP standards. }\end{array}$ & Often persistently cashflow negative & $\begin{array}{l}\text { Most biotechnology companies are } \\
\text { acquired by established } \\
\text { (bio)pharmaceutical partners while } \\
\text { cashflow negative. Therefore, } \\
\text { governance structures must effectively } \\
\text { balance the need to drive potential } \\
\text { acquisition value through investment, } \\
\text { while diligently managing current and } \\
\text { future liquidity requirements. }\end{array}$ \\
\hline Role of academics & $\begin{array}{l}\text { Academics, many of whom with limited } \\
\text { or no commercial experience, often } \\
\text { have significant roles in the formation } \\
\text { and ongoing operations and/or } \\
\text { governance of biotechnology } \\
\text { companies. }\end{array}$ & $\begin{array}{l}\text { Significant NGO and/or public sector } \\
\text { support }\end{array}$ & $\begin{array}{l}\text { Early stage biotechnology companies } \\
\text { are often recipients of significant non- } \\
\text { dilutive funding support by public sector } \\
\text { and philanthropic organisations. Such } \\
\text { funding necessitates detailed reporting } \\
\text { and governance requirements that early } \\
\text { stage biotechnology companies are not } \\
\text { appropriately structured or resourced to } \\
\text { deliver. }\end{array}$ \\
\hline \multirow[t]{2}{*}{ Highly skilled human capital } & $\begin{array}{l}\text { Tremendous investment in attracting, } \\
\text { training and retaining specialist } \\
\text { biotechnology skills is essential to the } \\
\text { success of all biotechnology companies. }\end{array}$ & Reporting bias & $\begin{array}{l}\text { The majority of biotechnology start-ups } \\
\text { fail before a major value inflection point } \\
\text { or acquisition. Therefore, there is a } \\
\text { reporting bias whereby unsuccessful } \\
\text { companies do not document or report } \\
\text { the reasons - governance related or } \\
\text { otherwise - which contributed to their } \\
\text { failure prior their cessation. }\end{array}$ \\
\hline & & Inexperienced management & $\begin{array}{l}\text { Often technical founders have deep } \\
\text { expertise in a rapidly emerging scientific } \\
\text { domain, but limited management } \\
\text { experience. There is also a trend for } \\
\text { senior management from non- } \\
\text { biotechnology sectors to be instituted in } \\
\text { early stage companies (Belussi 2015). } \\
\text { They are not always able to adapt rapidly } \\
\text { to the norms and requirements of the } \\
\text { biotechnology sector. It is critical that }\end{array}$ \\
\hline
\end{tabular}




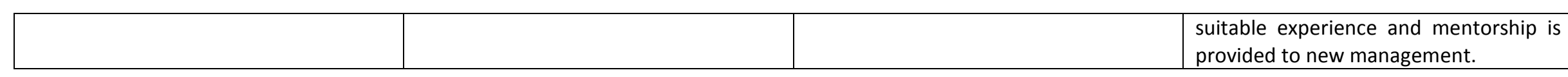




\section{A Proposal for Minimum Standards in Biotechnology Corporate Governance}

The authors put forward the following as a proposal for potential attributes of minimum standards in biotechnology corporate governance. These potential attributes are based upon the authors' experiences - not relating to any specific organisation(s) - and a review of the research literature in the area, in addition to semistructured workshops amongst the authors and collaborators.

These potential minimum standards are not intended to be definitive or exhaustive. However, it is hoped that they provide a substrate for more in-depth discussion, research and future sector-wide engagement. The advent of Web 2.0 (DiNucci, N, 1999) brought with it new household names and technologies, including Facebook, Google, Twitter and UBER. This was not complemented by Web Governance 2.0. In part, as a consequence, we have seen these and other unicorn companies gripped by corporate governance battles and major public failures in key functions, not least in the area of data protection.

While improved corporate governance from the inception of these companies could not have conclusively avoided such public falls from grace and public loss of confidence in the sector, it is axiomatic that it would have reduced the risk of such occurrences, and certainly provided pre-defined frameworks for management and Board responses to challenges once they occurred (Spitzeck, 2010). The biotechnology sector must learn from Web 2.0.

The time for Biotechnology Governance 2.0 is now.

\section{Proposed Minimum Standards in Biotechnology Corporate Governance}

1. Codification and documentation of a corporate governance system, including committee terms of reference. It is not effective or appropriate to rely on 'word of mouth' agreements or reverting routinely to Articles of Association to resolve moderate conflicts.

2. Non-Executive Directors (NEDs) should be appointed upon company formation, and the number of NEDs and their respective expertise increased throughout the company's lifecycle such that there is a majority upon the achievement of specified major milestones; for example, first-in-human trials.

3. The (voting) majority of all BoD Committees, including remuneration and audit, should be independent NEDs.

4. A regular independent review of critical BoD and management decisions should be conducted with defined corrective and preventative actions (CAPAs) executed. This review and CAPAs arising should be shared with shareholders and other interested parties; for example, company legal and financial advisors. Where possible a governance effectiveness rating or assessment system should be utilised.

5. Commencing with all corporate functions, an organisation wide quality management system (QMS) to a recognized, externally validated and appropriate standard; for example, ISO 9001 and/or ISO 13485, should be implemented and continuously reviewed and adapted to changing organizational needs.

6. Key BoD appointments (including to BoD committees), BoD member proxies and NEDs should be finite in duration and a process for review, reappointment and recruitment defined.

7. Governance by Design (GbD) - all governance procedures should be appropriate and proportionate to organizational needs, subject to regular review and updates.

8. Clear mechanisms should be agreed and defined by management and the BoD to cascade critical BoD decisions to all business functions effectively.

9. Training should be provided to BoD members to ensure an appropriate common baseline level of technical, regulatory and governance knowledge is achieved amongst all BoD members. This should be recorded in a formal training record and requirements for further training reviewed regularly.

10. BoD and management such seek to identify, adapt and/or remove obsolete BoD functions that are no longer required at a particular stage in organizational development.

11. Clear dashboards, balanced scorecards and updates to be exchanged between BoD and management to ensure effective communication and 'translation' of decisions and progress of actions throughout organizational functions, thereby ensuring that all parties have access to the same minimum standard of information to inform decision making.

12. Traditional internal corporate governance controls, non-specific to biotechnology, should be implemented. For example, appropriate financial authorization levels, segregation of duties, effective management of conflicts of interest and so on. 
13. All Advisory Boards, for example, Scientific Advisory Boards, should be regularly reviewed to ensure that skills and expertise appropriate to an organization's stage of development are represented, per Governance by Design. All appointments should be fixed term in nature.

14. All conflicts of interest amongst management and BoD members should be documented and effectively managed. For example, per corporate convention in Europe, the Chairman should ask all members of management and BoD to advise of any material changes to their conflicts of interest at the start of all BoD meetings.

15. Detailed due diligence on all staff and BoD members should be undertaken to ensure that individuals have appropriate qualifications and experience to deliver their functions effectively. If deficiencies are identified, the organisation must offer, and the individual concerned must undertake, appropriate training.

16. BoD must make documented, proportionate and appropriate efforts to promote diversity and inclusion amongst the BoD, management and in vendor selection processes continuously.

17. Where a shareholder and/or BoD member wishes to appoint a proxy to participate in the BoD on their behalf, mechanisms for appointing the proxy, the scope of the proxy's decision-making authority, direct communication routes between the BoD and the beneficial owner, and procedures for providing feedback to the beneficial owner in regard to their proxy should be defined. All investor proxies should be fixed term in nature.

\section{The Future of Biotechnology Corporate Governance}

Amongst inherent uncertainties in biotechnology development, some constant currents are defining the future of the sector and the organisations within it. Firstly, the technology platforms used to support developments by biotechnology companies will continue to grow in complexity and cost. Secondly, as technical complexity simultaneously broadens and deepens within specific domains, the availability of appropriately skilled human capital - with an apt blend of technical, management, strategic and governance expertise - will fail to meet demand at an ever-increasing rate. Thirdly, unmet medical needs will continue to grow as society's ability to pay for novel treatments decreases. Finally, investors with a risk appetite for biotechnology assets will continue to be required to fund all stages of company lifecycles. So, amongst these sector constants, where is the need for Biotechnology Governance 2.0?

Without appropriate governance and oversight, tool and technology developers will not make the right resource allocation or technical decisions to ensure that therapeutic and diagnostic developers have access to the tools they need, when they need them - without which delays in development and an increase in end product costs will occur. This also increases the likelihood of company failure, and investor losses.

These authors have experienced first-hand - and on multiple occasions - growing unmet medical needs, and non-specialist investors committing capital to biotech for the first time, 'burnt' not by poor technology or a lack of market pull, but by a lack of robust, proportionate and appropriate corporate governance.

If you work in a biotechnology organisation where the BoD regularly reaches non-unanimous decisions due to poor communication, vested interests or individuals simply 'passing the buck', it is late - but never too late - to institute improved corporate governance. If you work in a biotechnology organisation without these aforementioned problems, you should reflect on the governance procedures you have in place and ensure that these are continuously reviewed and implemented to prevent a swift and precipitous transition to the former situation detailed above.

Governance in any form is ultimately about the effective monitoring and accommodation of stakeholder interests. Biotechnology is potentially unique amongst sectors in the breadth and dynamic nature of its stakeholders at different stages of organizational development. As a consequence, we have potentially all been guilty of focusing too closely on the needs of one stakeholder and/or of omitting the needs of another.

Biotechnology governance is about balancing interests, objectives and resources in a manner that is not instantaneous but is consistent. These authors urge all members of the biotechnology sector to seize the opportunity to deploy Biotechnology Governance 2.0 as a stabilizing tool in a proactive manner in the inherently high risk, high stakes and high uncertainty world of biotech. Reactive governance is often akin to shutting the stable door after the genetically re-engineered horse has bolted ... 


\section{Bibliography}

Backhaus, K. (2015). The Role of International, Technological and Social Context in Considering Strategic Alliances in the Biotech-Pharmaceutical Industry.

Belussi, F., \& Orsi, L. (Eds.). (2015). Innovation, alliances, and networks in high-tech environments. Routledge.

Billitteri, C., Nigro, G. L., \& Perrone, G. (2013). How risk influences the choice of governance mode in biopharmaceutical inter-firm relationships. International Business Review, 22(6), 932-950.

Brindley et al (2015) Application of Real-Time Release Testing for the Biomanufacture of Autologous Cell-Based Immunotherapies, Bioprocess International

Cadbury A. in 'Global Corporate Governance Forum', World Bank, 2000

Carter, A., Meinert, E. \& Brindley, D.A. (2018) Data and Corporate Governance in Pharma and Digital Health: A Necessary Regulatory Convergence. (Available Ahead of Press)

Caulfield, T., Einsiedel, E., Merz, J. F., \& Nicol, D. (2006). Trust, patents and public perceptions: the governance of controversial biotechnology research. Nature biotechnology, 24(11), 1352.

Daines, R. M., Gow, I. D., \& Larcker, D. F. (2010). Rating the ratings: How good are commercial governance ratings?. Journal of Financial Economics, 98(3), 439-461.

DiNucci, Darcy (1999). "Fragmented Future" Print 53 (4): 32.

Fidler, A. and Msisha, W. Governance in the Pharmaceutical Sector Eurohealth 14:1, 2008

Guo, W. C., Shiah-Hou, S. R., \& Chien, W. J. (2012). A study on intellectual capital and firm performance in biotech companies. Applied Economics Letters, 19(16), 1603-1608.

G20/OECD Principles of Corporate Governance, 2015

Hogarth, S., \& Salter, B. (2010). Regenerative medicine in Europe: global competition and innovation governance. Regenerative medicine, 5(6), 971-985.

Nielsen, B. B. (2010). Strategic fit, contractual, and procedural governance in alliances. Journal of Business Research, 63(7), 682-689.

Nigro, G. L., Perrone, G., \& Chiapparrone, S. (2012). Governance forms drivers in bio-pharmaceutical inter-firm relationships. International Journal of Production Economics, 140(2), 604-613.

'The Report of the Committee and The Code of Corporate Governance' produced by The Committee on Corporate Governance or CGC, Monetary Authority of Singapore, 21 March 2001

Shleifer A. \& Vishny R. W., 'A Survey of Corporate Governance', The Journal of Finance, 1997

Spitzeck, H., \& Hansen, E. G. (2010). Stakeholder governance: how stakeholders influence corporate decision making. Corporate Governance: The international journal of business in society, 10(4), 378-391.

Strömsten, T., \& Waluszewski, A. (2012). Governance and resource interaction in networks. The role of venture capital in a biotech start-up. Journal of Business Research, 65(2), 232-244.

Swan P. \& Garvey G., 'The Economics of Corporate Governance: Beyond the Marshallian Firm', Journal of Corporate Finance, 1994 
Wolfensohn J., former President of the Word Bank Group, as quoted by an article in Financial Times, 21 June 1999

Zingales L., 'Corporate Governance'. In Peter Newman (Ed.), The New Palgrave Dictionary of Economics and the Law (pp. 497-502), London: Macmillan, 1998 